\title{
Let me tell you something about (y)our culture?
}

\author{
Mícheál Mac an Airchinnigh \\ School of Computer Science and Statistics, University of Dublin, Trinity College, Dublin 2, Ireland. Email: \\ mmaa@cs.tcd.ie
}

\begin{abstract}
Each person is born into a culture that is mediated by the mother tongue. Further development of the person is often associated with schooling and education. At an early age some persons will come into contact with other cultures especially if living in a cosmopolitan city or through frequent travel. Such intercultural contact consists of exposure to another tongue, initially aural, and images of the other, perhaps in the form of dress, or architecture, and so on. In the digital world of 2010 those who surf the electronic wave constantly dip in and out of many cultures. Those who normally use Wikipedia in English might over time also refer to a version of an article in another tongue. Those who are frequent users of YouTube might be curious enough to watch a video clip in Turkish or in Greek as well as the usual English, in the context of a history lesson in school. Culture in the digital world needs to be supported and sustained. Are you looking for something? Try Google or Bing or... You have found something you want to share? Post a video clip, or a photograph, or a piece of music. But how shall we keep track of this digital culture? Why would we want to? In this paper we will address the fundamental problem of how to manage cultural information in an integrated fashion in the world of Art. To be specific we will use Bulgarian Art to inform one aspect of Turkish culture.
\end{abstract}

Keywords: digital re-discovery of culture, empathy, folksonomy, keyimage, memory, museum of innocence, ontology.

\section{Before we begin in earnest...}

"Since the time when more than a century ago... the figure of the so-called Thracian Horseman stood out as the most important diagnostic characteristic of that Thracian heritage... reliefs found (numbering more than 1500 from various parts of Bulgaria...)" (Toporov, 1990)

When I recently came across this quoted text on the "Thracian Horseman" in the journal article cited, the image of the Madara Horseman (UNESCO World Heritage Centre, 1979) immediately sprang to mind. I can not tell if the Madara Horseman ${ }^{1}$ is one of these "Thracian Horsemen" implied in the text above. I can tell that I have been to that place near to the village of Madara and have seen for myself, this extraordinary image. Anyone with Internet access can see the image online. And Google Earth will fly you there. It is Google Earth that provides some sort of geographical context - the factness of the plateau rising up out of a flat surrounding plain. To be there in person, to experience the... ${ }^{2}$ And so, from this experience one is led directly to the "not so modern" phenomenon of cultural tourism (Wikipedia, 2010a). One of the consequences of such tourism is often to report back home on what has been seen and experienced. It is not usually the case that one reports back to those, whose culture one has experienced. A major stumbling block is often the natural language ${ }^{3}$ of the visited culture. And before the "coming into being" of the widespread Web, to what other kind of person might one want to report to?

I had seen the Madara Horseman long before I read the journal article. The reading of the article brought back instantly that memory of seeing. It has been and still is customary for us to be acquainted with cultural artefacts, such as sculptures, paintings, manuscripts and so on through the medium of print, often in newspapers and magazines. These latter physical objects have been the stage, the platform, from which each reader breaks out into an imagined world mediated through the print. This leaping out of the imagination from the printed world is at the very heart of print advertising. The book often plays a special role in opening up a culture to another. Historical novels and Memoirs are classic examples. Of particular importance for our "telling about the culture of the other" is the recent work of Orhan Pamuk, The Museum of Innocence (Pamuk \& Freely, 2009), a work, a novel, that reveals more of the upper class society of Istanbul from which he himself springs. It is a text, a story, a truth revealed, in much the same

${ }^{1}$ It is noteworthy that the UNESCO World Heritage Centre uses the phrase Madara Rider instead of Madara Horseman. Is this an example of "political correctness"?

${ }^{2}$ The rest of the text is deliberately omitted. It is assumed that the reader can fill in their own text with respect to a similar sort of cultural experience. For example, one might imagine a reader from Turkey, visiting Ankara for the very first time and being brought to see Anitkabir. What sort of crossover cultural connections might (s)he then make?

${ }^{3}$ Even when the "same language" is involved, such as English, there may be significant cultural differences. A good example might be the difficulty that some American visitors might have after visiting English speaking countries such as Ireland, Scotland, Wales, and even (parts of) England. 
spirit as his own childhood and teenage years were opened up in the earlier Istanbul, Memories of a City (Pamuk, 2005). And Pamuk is directly involved in the design and manipulation of the photograph that is used on the cover jacket of the book. There is a car in which three man and two women look at the photographer. But the original background of woodland from somewhere in Turkey's interior has been replaced with the well-recognized Bosphorus (Quinn, 2010). Pamuk speaks through his translator. Pamuk speaks as one, today, displaced from his cultural roots. The narrator of the Museum of Innocence pinpoints the 23-year old chain-smoking Orhan Pamuk as one for whom there is "nothing special about him beyond his propensity to act nervous and impatient, affecting a mocking smile." p.116-7.

I have been to the street of the Pamuk Apartments, Istanbul, in 2007. I have read all of his books that have been translated into English. I think I know a little of the culture about which he speaks. His works brought me to Istanbul, to Ankara, to Turkey, to understand and empathize with a culture, very different from my own. Through his books Pamuk has implicitly put to me, personally, the rhetorical question "Let me tell you something about your culture?" And in this most recent of his novels he puts the question to the "City of Istanbul, European City of Culture", in July 2010 (Hurriyet Daily News and Economic Review, 2010) ("Istanbul 2010 - European Capital of Culture," 2010). The electronic version of the Museum of Innocence is already live in Turkish (Masumiyet Müzesi, 2010) and thoughtfully Pamuk gives the physical location on a map in the book: on the corner of Çukursuma Cd. and Dalgı̨̧ Çk. (Google Earth, 2010) $)^{4}$.

"Anyone remotely interested in the politics of civilization will be aware that museums are the repositories of those things from which Western Civilization derives its wealth of knowledge..." (Pamuk \& Freely, 2009, p. 73)

Before I read the works of Orhan Pamuk, (we are of the same generation), I already knew Bulgaria, its people, its culture. Today, I realize that I also had begun the construction of my own "Museum of Innocence" in 1979". Today, in the light of Pamuk's initiative, I think it would be good to mention some of the objects that I will put in my Museum in 2010.

The image of the Madara Horseman is on one side of the 50 stotinki Bulgarian coin (Орела, 2010), from which one may infer that the image is an intrinsic part of the Cultural Heritage of Bulgaria. I have added it ${ }^{6}$ to the Museum collection. I often wonder to what extent the "average Bulgarian" is affected culturally by this image on the coins. Does $\mathrm{s}(\mathrm{he})$ learn of its importance through the elementary schooling system? I compare myself with that other and ask to what extent does the "average Irish person" appreciate the meaning of the image of the harp on the reverse of the (formerly) Irish and now European (Irish) coins.

In February 2009 there appeared an article describing a Madara-like Horseman in Shamark, Afghanistan (Георгиева, 2009). When I learned of it and looked at the image (on the Internet) I was astonished. I will probably never visit Afghanistan. But the experience of the Madara Horseman already informs me of a little something of the culture of those who made that image. And the 50 stotinki coin currently in my Museum provides a keyimage for the Horseman in Shamark. The images are on the Web. You can compare them to see how alike they are. You too might like to open up your own "Museum of Innocence"?

\section{Serendipity}

A book, like Pamuk's "Museum of Innocence", offers an opportunity to the reader to break out into another culture, another era. In earlier times such book breakout was often confined to the physical libraries and museums in the vicinity. All that is now changed by the Web. Let us now turn our attention to works of art, such as sculpture and painting. A sculpture, such as the monumental Lozan Anit1, Edirne (Орела, 2008) can only be visited or photographed. The photograph of Lozan Anit1 is freely available in many places on the Web (Koruma, 2008). The photograph can never replace the (experience of the) original artwork. But that is true of all such things. A painting stands in a similar fashion. It might be in private hands and, therefore all but the owner and family and friends, are excluded from seeing it. If a photograph or a copy/facsimile/print exists then others may get to experience something of the original. A painting such as Picasso's Guernica (Picasso, 1937) is on the same scale of inaccessibility as the Lozan Anitı monument. A photograph or print does not (usually) capture the monumental size of the original work. One might imagine a LED screen technology of the future which would "recreate" Guernica in monumental copy form.

\footnotetext{
${ }^{4}$ Locating the Museum of Innocence via Google Earth took about 30 minutes. I am almost certain that I have the correct coordinates. It is proposed to test this in the field using a suitable mobile phone such as Android, iPhone, Nokia,... device.

${ }^{5}$ The year 1979 is chosen to correlate exactly with what the author regards as the opening date for the memory collection.

${ }^{6}$ By "it" I mean the image of the Madara Horseman photographed. The coin must be returned to the country to which it belongs. And now I realize that I have become an accidental coin collector over a lifetime.
} 
It the modern world of social networking (Krotoski, 2010), whether for personal or professional purposes, it is normal for people to share their "cultural interests". For the "young" such interests are often related to music or film. Photographs will also have their place. Such "practical sense" suggests a working hypothesis. Philosophically, the medium has changed, not the nature of the interest. So it will be for all. If people do not normally go to Art Galleries to look at certain exhibitions or paintings, then there is no reason for them to do so online. People must be enticed... somehow. To explore this hypothesis let us consider a thought experiment? Let us imagine that you see, for the very first time, a particular picture. Maybe you come across it in a National Art Gallery, such as Dublin or Sofia, or perhaps you see it, by chance, online (Georgi Danchov (1846-1908), 1867). Imagine that it is on exhibition in Istanbul in July 2010 to celebrate the year of culture? We summarize these "scenarios of seeing" by placing them in the context of a serendipity hypothesis - the fortuitous accident that opens the door into another cultural world ${ }^{7}$. A typical invitational text might take the following form:

Let us consider the picture of "The Man in the Red Fez" (Georgi Danchov (1846-1908), 1867).

What do you see? Can you describe what you see in a few short sentences?

The given title "The Man in the Red Fez" is not the real title of the painting. It is a folksonomical title that anyone might use if (s)he were familiar with the type of hat shown (Wikipedia, 2010d). This particular experiment could only be carried out since mid-2009 when the image became available online. Here is the background scenario designed to focus on a particular aspect of culture.

In our modern times (2010) the deliberate choice of the use of the word Fez in the title of the painting, rather than Hat, will in all probability suggest to the curious one, the desire or need to a) search with Google, b) search Wikipedia, or even c) search "an online dictionary" such as Wordnik (Wordnik, 2010). The Wikipedia article gives a focused though ambiguous result: 11 possibilities, of which the $3^{\text {rd }}$ brings one to the hat interpretation (Wikipedia, 2010c). A subsequent quick perusal of the Wikipedia text will lead one directly to the text:

"In Turkey, wearing the fez was legally banned in 1925 as part of the modernizing reforms of Mustafa Kemal Ataturk."

That picture of the man in the red $\mathrm{fez}^{8}$ is now hanging in a prominent place in my museum ${ }^{9}$. The curious will wonder why the fez was banned. Tourists can still buy the fez in Istanbul, for example. But it is not the real thing ${ }^{10}$ (Manon van der Lit, 2008). The painting "The Man in the Red Fez" is a keyimage. It unlocks the door to a very special place in Balkan and Turkish history. What kind of place might that be?

In "my picture of the world", the banning of the fez brings to mind some immediately some very beautiful portraits of Mustafa Kemal Ataturk (Wikipedia, 2010f) which are on display in the War of Independence Museum (T.C.Genelkurmay Başkanı̆̆ı): captioned" "Gazi Mustafa Kemal riding the horse $\mathrm{e}^{12}$ called „Sakarya“" (undated), "Command-in-chief Marshal Gazi Mustafa Kemal” (1922) and "President Gazi Mustafa Kemal" (1923). In each of these pictures a black hat of a certain form is worn. It is of a different style to the fez. I wonder about the name and origins of this black headpiece. And for the "modern generation" let us introduce a YouTube clip showing some very old film which gives one some further idea of the headdress styles around 100 years ago ("Mustafa Kemal Ataturk Pasa," 2010).

Let us return to the painting "The Man in the Red Fez" and its location. The visitor to the art gallery in question (whether in Sofia or online) will see that the man in the red fez is a painter by the name of Georgi Danchov (Georgi Danchov (1846-1908), 1867). A search in Wikipedia will reveal that a) there is no page in English for him, and (b) he was an associate of Vasil Levski ${ }^{13}$. There is, of course, a page for Георги Данчов in the Bulgarian Wikipedia. And every Bulgarian knows the significance of Vasil Levski, a person on a par with Mustafa Kemal Ataturk for those of Turkish culture.

${ }^{7}$ Such a cultural world might very well be one's own youthful cultural environment. I remember when I was 13 , and I remember walking out on the ice-covered lake. One year later I would leave home forever. This year, writing from another place, in 2010 , has the feeling of 1963 , all over again.

8 The emphasis on "red fez" is deliberate. If used on its own, it is assumed that the fez is red. However, other colours of fez are in current use. There are pictures of Mustafa Kemal where he appears to be wearing a black fez.

${ }^{9}$ http://www.flickr.com/photos/mihalorel/4268360773/

${ }^{10}$ Where did I read this recently (January 2010)? Was it in a newspaper? Did it read it online? Sometimes one does forget to mark the source. When I was in Istanbul in 2007, I do not recall seeing a fez for sale.

${ }^{11}$ I have no information on the name of the painter who executed these works. How might one find out on the Web?

12 Deliberately chosen to reflect back to the Madara Horseman. The significance of the Horseman (Centaur) is deeply rooted in certain cultures. In particular, let us single out the significance for nomadic culture, especially the culture of so called protobulgarians, among which is the founder of Bulgaria, Khan Asparuh.

${ }^{13}$ The omission of reference material to Vasil Levski is deliberate in view of the game yet to be played. 
Although the wearing of a Fez is not and never has been a part of "my" culture, I have a "feeling for" those cultures in which it was (and still is). Part of that feeling is not only visual but one of feeling, experienced through music ("Anadolu ateşi (The fire of Anatolia)," 2004). That is to say, I listen to the latter as I am writing and remembering. And remembering the year of the Fez ban (1925) brings one back to that time when the centre of power shifted from Istanbul to Ankara. And from a Culture point of view one might say that today in 2010 there is a refocusing of "the" culture in Istanbul (Hurriyet Daily News and Economic Review, 2010). In today's electronically connected world one can get a sense of the fire of Anatolia on YouTube (YouTube, 2004b), and the experience will trigger remembrance of Riverdance among people of "modern Celtic culture) (YouTube, 1994). Ten years after Eurovision in Dublin, Istanbul opened with Sertab Erener, and at the end of her performance (part 2) a well-known hat appeared, not a fez but the headdress of the Sufi (YouTube, 2004a).

Let us conclude this section by explicit reference to the kinds of headdress worn by males and the cultural significance of same. Males in the army and in the police also use distinctive headdress. Under current equality legislation in many cultures, females wear the same sort of headdress as the males, an interesting development in our times. In some cultures, the male headdress can be very provocative. One classic example is that of the Sikh's turban (Sikhi Wiki) which came into conflict with the headdress to be worn by the police. Another provocative situation arises in the wearing of the "bowler hat" in Northern Ireland (Demotix, 2010).

\section{Keyimage and ontology}

From an information management perspective we shall find a (personal) need to classify what we have unearthed from this self-portrait of Georgi Denchov and his fez. It is our need, precisely because we have discovered this chain of thoughts and events from a particular source: a picture, something which we will call a keyimage. And it is the Red Fez in the picture which makes the latter a keyimage. From the point of view of the CIDOC-CRM (Schiemann, Oischinger, \& Görz 2009), the object "Red Fez" which is portrayed may be formally classified as an E22 Man-Made Object. But surely this real "Red Fez" object of 1867 no longer exists? If it does then we may formally record certain properties that it possesses, such as P54 has current permanent location, and so on.

The building up of large-scale relevant ontologies is a massive and competitive task. There are professional bodies for which such ontology-building is their "bread-and-butter". Consider, for example, the Getty Research unit (The GETTY). Let us look to see if they have any record of a famous Bulgarian artist ${ }^{14}$ such as Ivan Milev (Wikipedia, 2010e)? Using the GRI Catalog Plus (BETA) [2010-01-16] returns 0 results in all categories. On the other hand, a search in their Union List of Artist Names [2010-01-16] gave 1 result, the one desired. Curiously, a search of the same list with Иван Милев, led to

\section{http://www.getty.edu/redirect/500.html?error=java.lang.ArrayIndexOutOfBoundsException}

and an on-screen message :

"We're sorry - we are currently doing maintenance on the site. Please try again in a few minutes."

Whatever process is used by Getty Research, it seems to me to be clear, at this time, that they are not "scraping" Wikipedia pages (in any language) for possible candidates to add into their databases.

Page scraping by Web spiders is currently one of the practical ways to harvest data. What Google does, works extremely well, and to a certain extent depends entirely on what we humans contribute as data. Tim Berners-Lee already expressed this idea (Berners-Lee \& Fischetti, 2000, p. 189), suggesting that "documents [...] created within the same logical framework, such as RDF, [will lead to] partial understanding [ and that] This is how computers will work across boundaries, without people having to meet to agree on every specific term globally."

We can explore the state "of the art" (pun intended) by choosing some "official pages" of Art Galleries and viewing the source. For "our man" with the Red Fez, the relevant code is

Table 1 Information gleaned from Web Page

$$
\begin{aligned}
& <\text { table width="1" height="1" border="0"cellpadding="4"> } \\
& <\text { tr }><\text { td style="border: solid \#DCDFE6 3px;" > } \\
& <\text { img src="upl/img/129.jpg"/> }
\end{aligned}
$$

\footnotetext{
${ }^{14}$ We use Ivan Milev rather than Georgi Danchov to illustrate the use of the Getty research tools. Georgi Danchov does not even turn up in the Union List of Artist Names.
} 


$$
\begin{aligned}
& </ \text { td }></ \text { tr }> \\
& </ \text { table }> \\
& <\text { br }><\text { br }>
\end{aligned}
$$

Автопортрет, 1867

$<$ br $>$

Георги Данчов (1846-1908)

The corresponding English version differs only in the last three rows:

Table 2 Corresponding English text

Self-portrait, 1867

$<\mathrm{br}>$

Georgi Danchov (1846-1908)

There is no mention of a "Red Fez". That is not surprising. But the very fact of the absence of "Red Fez" or "Червен фec" means that this picture will not be found directly on its home web site if we use these search terms. This representation of a work of art is not unusual. In his paper "How formal is the structure of historical knowledge?" Martin Doerr, highlighted the fundamental problem in a keynote presentation on the CIDOC-CRM in the First International Workshop [on] Ontology based modeling in Humanities:

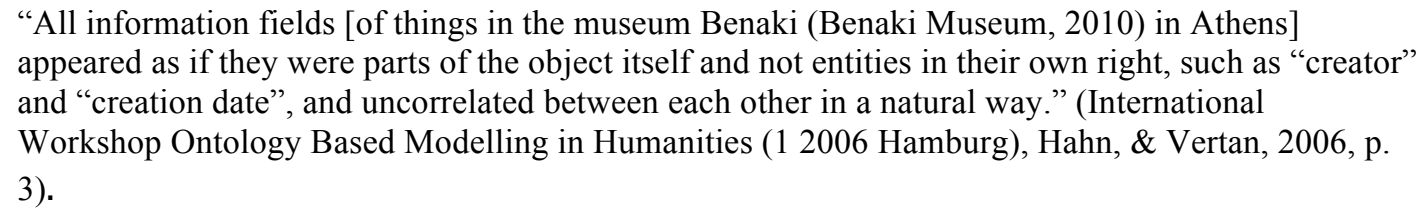

We note that this problem also pertains to the painting which we have called "The Man in the Red Fez". The painter is listed as "Georgi Danchov (1846-1908)." As humans we know that Georgi is the first name, that Danchov is the family name. We infer that this is the name of the painter. This supposition is confirmed by the title of the painting: "Self-portrait." The date range is understood to give his birth: 1846 and his death: 1908. Finally, the painting is dated 1867. If we add in the (original) Bulgarian text for the same painting we, as humans, may deduce that "Георги Данчов" corresponds exactly to "Georgi Danchov."

\section{Ontological detail}

Before the existence of the CIDOC-CRM I used a simple ad-hoc ontological structure for research into Cultural Heritage, with special focus on Art. In particular under the Class Person, I used subclasses Artist, $\underline{\text { Owner, and }}$

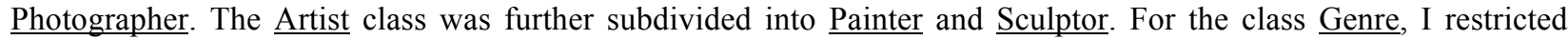

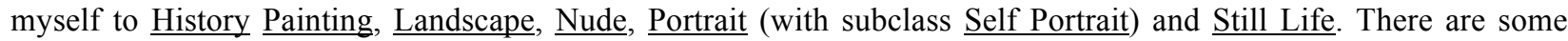
interesting problems associated with the unique identification of a Painting, for example. Consider the portrait of Ataturk in 1923.

Introduction of the CIDOC-CRM required that my Person class be made equivalent to the E21 Person. This sort of action goes by the name of ontological alignment (Lockheed Martin Corporation, 2005; Wikipedia, 2010g).

For the class $\underline{\text { Person, }}$, the properties of birth date [P981 was born], death date, and death place were regarded to be fundamental. Another property, unique to the author, was that of a keyimage. For the painting in question, "The Man in the Red Fez," the most important thing to do is to give it some sort of unique identity. Doubtless the National Art Gallery in Sofia has such an identifier, required by Bulgarian law, and inscribed both on the Passport as well as the Dossier of the painting. Unfortunately, I am not currently privy to that information. For the purposes of research, a unique name (technically a URI) can be assigned within the framework of Flickr. Currently, a version of "The Man in the Red Fez, is located at the unique address: 
This address is re-encoded for the CIDOC-CRM OWL ontology within Protégé in the form Place_Flickr_mihalorel_4268360773 and annotated using Dublin Core (DCMI) metadata:

Source: http://www.flickr.com/photos/mihalorel/4268360773/

Table 3 Dublin Core metadata for "The Man with the Red Fez" painting, 1867

\begin{tabular}{|c|c|}
\hline cont & An entity responsible for making contributions to the resource.) Михал Орела \\
\hline cove & $\begin{array}{l}\text { (The spatial or temporal topic of the resource, the spatial applicability of the resource, or the } \\
\text { jurisdiction under which the resource is relevant.) }\end{array}$ \\
\hline creator & (An entity primarily responsible for making the resource.) Георги Данчов (1846-1908) \\
\hline date & $\begin{array}{l}\text { (A point or period of time associated with an event in the lifecycle of the resource.) 2010- } \\
01-16\end{array}$ \\
\hline description & $\begin{array}{l}\text { (An account of the resource.) The resource is considered to be that photograph of the } \\
\text { original painting (self portrait) of Georgi Danchov, } 1867 \text {. The photograph in question is } \\
\text { located on Flickr with URI http://www.flickr.com/photos/mihalorel/4268360773/ }\end{array}$ \\
\hline format & $\begin{array}{l}\text { (The file format, physical medium, or dimensions of the resource.) The format is jpeg: } \\
\text { http://farm5.static.flickr.com/4015/4268360773 caac7f3e33 o.jpg and has dimensions } \\
\text { width="500" height="706" }\end{array}$ \\
\hline identifier & $\begin{array}{l}\text { (An unambiguous reference to the resource within a given } \text { context.) } \\
\text { http://www.flickr.com/photos/mihalorel/4268360773/ }\end{array}$ \\
\hline language & $\begin{array}{l}\text { (Recommended best practice is to use a controlled vocabulary such as RFC } 4646 \\
\text { [RFC4646].) en }\end{array}$ \\
\hline publisher & (An entity responsible for making the resource available.) Михал Орела, Flickr. \\
\hline relation & (A related resource.) http://www.nationalartgallerybg.org/index.php?l=55\&id=28 \\
\hline rights & $\begin{array}{l}\text { (Information about rights held in and over the resource.) Since the resource referred to is on } \\
\text { Flickr, then one is referred to http://creativecommons.org/licenses/by/2.0/ }\end{array}$ \\
\hline source & $\begin{array}{l}\text { (A related resource from which the described resource is } \\
\text { http://www.nationalartgallerybg.org/index.php? } 1=55 \& \mathrm{id}=28\end{array}$ \\
\hline subject & (The topic of the resource.) painting, oil on canvas, self-portrait, Georgi Danchov \\
\hline title & (A name given to the resource.) Автопортрет 1867 \\
\hline type & genre of the resource.) digital photograph \\
\hline
\end{tabular}

\section{Comment and assessment}

It is quite tedious to produce Dublin Core (DC) metadata by hand. Moreover, notice that the 15 elements are listed in alphabetical order. This is also the order used in the CIDOC-CRM OWL ontology running in Protégé 4. Machines do not really care what order metadata elements are listed. From a human perspective, the DCdot tool (Powell, 2000) may be used. Let us look at another portrait by the artist Georgi Danchov on the Web (Вестник "Марица"). Scraping the page for DC metadata using DCdot gives the following result:

Table 3 DCdot metadata for Newspaper Вестник "Марица"

Title

Creator (author)

Subject or keywords
Гледаме уникати на Георги Данчов-Зографина - Вестник "Марица"

SMS; 10:52; Martin; 19:37; 11:20; 10:39; Sport; 19:07; 14:31; 18:30; 19:40; 20:39; Diesel; maini4ka_1; btgeorgiev; 16:09; 20:08; 22:38; Google; Viscomp; niki8283; $21: 44 ; 14: 24$; Maps; 14:09; 21:48; 12:26; Arruor; Facebook; 0897/577-346; cunitooo; Delicious; 17:15; beninda; Digg; gorgona; Mercedes; 08:27; ogi_pld; Svejo.net; kasteli; 02:19; 21:26; 12:04 


\section{Description}

Publisher

Contributor

Date

Type Text

DCMI Type:

Format

text/html; charset=UTF-8 || 57465 bytes

Identifier

http://www.marica.bg/show.php?id=9047

Source

Language

Relation

Coverage

Rights management

It is the author's experience that DC metadata is often quite sparse for Newspapers online. It is also quite common to find that the "Subject or keywords" box is very large. It is the author's opinion that the quality of the DCdot data is often a good indicator of the online structure of the Newspaper in question. Hence one may say that the DCdot tool measures to a certain extent just how well the much mooted ontological infrastructure has actually penetrated in practice.

\section{Digital re-Discovery of Culture and the Game of Inquiry}

Very few people will ever visit the National Art Gallery (NAG), Sofia, and study the painting of "The Man with the Red Fez". Why would anyone want to? But now that there is a digital version of the painting on the NAG web site and, more importantly another digital version on Flickr, then we have the possibility of telling a story, many different stories, in fact.

One such story might begin with a simple observation:

"Once upon a time, there was a painter who liked to dress up. He was a very good painter. One day he said to himself, I think it is time to paint myself. I am 31 years of age. I am in the prime of life. I will put on my very best clothes and I will wear my lovely red hat."

Notice that there is no mention of the date 1867 and "red hat" is used instead of "red fez". Nor do we mention the fact that the painter is Bulgarian. To give very specific details of geographical and historical fact in a story will already bias the story. The full version of this story is to be used as a background, a stage setting, for a kind of play, a piece of theatre, a game ${ }^{15}$.

The next step in the preparation of our play will be the introduction of some scenery, some stage props. Why not introduce the Flickr address which gives access to the self-portrait of Georgi Danchov? Alternatively we can give the Wikipedia address of the page on which a "similar" self-portrait appears. This particular portrait is a keyimage in the play. It shows a well dressed man with a red hat. We might choose another image of a man with a similar looking hat from around the same era. What about the photograph of a pair of Bulgarian Turks from "село Бояна (Кокарджа) варненско" ("Български турци от село Бояна (Кокарджа) варненско, облечени в типични носии на заможни, млади мъже, с бели пояси и богато подшити с гайтани горни дрехи - около 1880-1890г.,")? This old photograph is black and white. We can only assume that the man on the left is wearing a red fez. Put the two images side by side and it is clear that the fez was worn both by elegant painters and more humble peasants. Such juxtaposition of two "opposing" images raises a question in the mind of the player of this "game".

In the English language, the notion of a game requires a set rules and, in addition a space in which the game is played (Salen \& Zimmerman, 2004). The space for the game of inquiry is the Web, augmented if necessary by one's

${ }^{15}$ In many languages there is no distinction between the word for play and the word for game. In Bulgarian there is just the one word ИГРА. Тhe author is playing a game with words deliberately. 
own physical resources. For example, the game being designed here requires the use of books and other physical things, such as prints of paintings. A reasonable account of the structure of the Game of Inquiry is available (Mac an Airchinnigh, 2008). Here we conclude with yet another summary attempt at describing the structure, the paraphenalia,... of the game of inquiry. In brief, there are 5 key elements: 1) the backstory (max 1 A4 page) which sets the scene for the drama to be enacted; 2) the set of keyimages (augmented with video clips, music clips, sound clips) which provides the scenery, the backdrop, the feeling of space, the mood of the piece; 3 ) the set of keywords or keyphrases that help to focus the direction in which the player makes a move; 4) the set of Web pages, each of which is a window onto a bigger relevant landscape; 5) the explicit stated goal of the game. Items 2 and 4 need to be kept low in numerical number. In particular, the use of Web pages as a breakout device is fraught with the possibility of delivering a "never ending story" type of game. Let us conclude the discussion with a game based on materials already presented? And what shall be the subject? Given the factness of Istanbul as EUropean City of Culture 2010 and the opening of the Museum of Innocence there in July, then it does seem to be appropriate to devise a game "out of' Orhan Pamuk's most recent novel. Space permits but a brief outline of the game:

\section{Backstory:}

"Mr. Orhan Pamuk recalled that Füsun had danced with two people early on. He didn't know or couldn't remember her first dance partner... The second, however, was the young man...-Orhan Pamuk himself... Those interested in Orhan Bey's own description of how he felt while dancing with Füsun should look at the last chapter, entitled "Happiness." (Pamuk \& Freely, 2009, p. 124)

Keyimages: 1. (Cargada de Libros, 2010), 2. (Andrew Findlater, 2008), 3. ("Istanbul Hilton,").

Keywords: hotel, engagement party, flying carpet canopy

Web pages: 1. (Wikipedia, 2010b), 2. ("Istanbul 2010 - European Capital of Culture," 2010), 3. ("İstanbul Hilton Oteli,").

Goal: Where did Orhan Pamuk dance with Füsun?

\section{Acknowledgements}

I am thankful to Kalina Sotirova for the reference to the Madara-like Horseman in Afghanistan and for pointing out the significance of the early nomadic culture such as that of the so called protobulgarians, among which is the founder of Bulgaria, Khan Asparuh. Thanks are due also to Kalina and my daughter Thérèse for proof reading an earlier draft of the paper.

\section{References}

Anadolu ateşi (The fire of Anatolia). (2004). İstanbul: Yeni Dünya Müzik.

Andrew Findlater. (2008). Pamuk Apartment, Nisantasi, Istanbul. Retrieved January 31, 2010, from http://www.flickr.com/photos/69331295@N00/2438784870/

Benaki Museum. (2010). Benaki Museum. Retrieved January 16, 2010, from http://www.benaki.gr/index.asp?lang=en

Berners-Lee, T., \& Fischetti, M. (2000). Weaving the Web : the original design and ultimate destiny of the World Wide Web by its inventor (1st pbk. ed.). New York: HarperCollins Publishers.

Cargada de Libros. (2010). El Museo de la Inocencia. Retrieved January 31, 2010, from http://www.flickr.com/photos/cargadadelibros/4288340993/

DCMI. Dublin Core Metadata Initiative. Retrieved June 26, 2009, from http://dublincore.org/

Demotix. (2010). Bowler Hats, Sashes and Banners: the Orange Order in Northern Ireland. Retrieved January 24, 2010, from http://www.demotix.com/news/30876/bowler-hats-sashes-and-banners-orange-order-northern-ireland

Georgi Danchov (1846-1908), Г. Д.-. (Artist). (1867). Self-portrait (Aвmonopmpem).

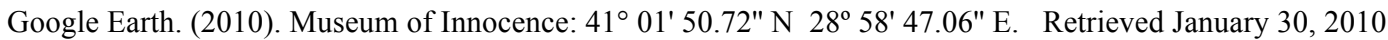

Hurriyet Daily News and Economic Review. (2010). Istanbul launches year as European culture capital. Retrieved January 24, 2010, from http://www.hurriyetdailynews.com/n.php?n=istanbul-launches-year-as-european-cultural-capital-2010-01$\underline{17}$ 
International Workshop Ontology Based Modelling in Humanities (1 2006 Hamburg), Hahn, W. v., \& Vertan, C. (2006). First International Workshop Ontology Based Modelling in Humanities : 7 - 8 April 2006, University of Hamburg. Hamburg: Univ. Hamburg, Bibliothek des Departments Informatik.

Istanbul 2010 - European Capital of Culture. (2010). Retrieved January 29, 2010, from http://www.en.istanbul2010.org/index.htm

Istanbul Hilton. Retrieved January 31, 2010, from http://www.diploma-unit-9.net/Omer/2008/11/hip hotel.html\#more

İstanbul Hilton Oteli. Retrieved January 31, 2010, from http://arkiv.arkitera.com/p2247-istanbul-hilton-oteli.html

Koruma. (2008). Lozan Anıtı. Retrieved January 30, 2010, from http://www.trakya.edu.tr/Koruma/Lozan Aniti.htm

Krotoski, A. (2010). The Virtual Revolution, How 20 years of the Web has reshaped our lives. Retrieved January 31, 2010, from http://www.bbc.co.uk/virtualrevolution/

Lockheed Martin Corporation. (2005). The Ontology Alignment Source. Retrieved January 16, 2010, from http://www.atl.external.lmco.com/projects/ontology/

Mac an Airchinnigh, M. (2008). The Digital Culture. Paper presented at the Balkan Ülkeleri Kütüphanelerarası Bilgi-Belge Yönetimi ve İşbirliği Sempozyumu.

Manon van der Lit. (2008). Red hat for your head... (Grand Bazar, Istanbul, Turkey). Retrieved January 31, 2010, from http://www.flickr.com/photos/bredero5/2633865053/

Masumiyet Müzesi. (2010). Retrieved January 28, 2010, from http://www.masumiyetmuzesi.com/public/

Mustafa Kemal Ataturk Pasa. (2010). from http://www.youtube.com/watch?v=avmRFsGoeKQ\&feature=related

Pamuk, O. (2005). Istanbul : memories of a city. London: Faber and Faber.

Pamuk, O., \& Freely, M. (2009). The museum of innocence (1st North American ed.). New York: Alfred A. Knopf.

Picasso, P. (1937). Guernica. Retrieved Feb 3, 2008, from http://en.wikipedia.org/wiki/Image:PicassoGuernica.jpg

Powell, A. (2000). DC-dot. Retrieved June 26, 2009, from http://www.ukoln.ac.uk/metadata/dedot/

Quinn, B. (2010). Pamuk Photoshops. Review Saturday Guardian 230110, p. 5.

Salen, K., \& Zimmerman, E. (2004). Rules of play : game design fundamentals. Cambridge, Massachusetts: The MIT Press.

Schiemann, B., Oischinger, M., \& Görz, G. (2009). Erlangen CRM Version 2009-03-30. Retrieved Apr 15, 2009, from http://www8.informatik.uni-erlangen.de/IMMD8/Services/cidoc-crm/erlangen-crm 090330_5 0 1.owl

Sikhi Wiki. Turban. Retrieved January 24, 2010, from http://www.sikhiwiki.org/index.php/Turban

T.C.Genelkurmay Başkanığı. ATATÜRK ve KURTULUŞ SAVAŞI MÜZESİ. (Ataturk and the War of Independence Museum). ISBN 975-409-343-1. Ankara.

The GETTY. The Getty Vocabularies. Retrieved January 16, 2010, from http://www.getty.edu/research/conducting_research/vocabularies/

Toporov, V. N. (1990). The Thracian Horseman in an Indo-European Perspective. Orpheus, Journal of Indo-European and Thracian Studies, 0, 46-63.

UNESCO World Heritage Centre. (1979). Madara Rider. Retrieved January 5, 2010, from http://whc.unesco.org/en/list/43

Wikipedia. (2010a). Cultural tourism. Retrieved January 26, 2010, from http://en.wikipedia.org/wiki/Cultural tourism

Wikipedia. (2010b). European Capital of Culture. Retrieved January 31, 2010, from http://en.wikipedia.org/wiki/European Capital of Culture

Wikipedia. (2010c). Fez (hat). Retrieved February 1, 2010, from http://en.wikipedia.org/wiki/Fez_hat) 
Wikipedia. (2010d). Fez_(hat). Retrieved February 1, 2010, from http://en.wikipedia.org/wiki/Fez_(hat)

Wikipedia. (2010e). Ivan Milev. Retrieved January 16, 2010, from http://en.wikipedia.org/wiki/Ivan Milev

Wikipedia. (2010f). Mustafa Kemal Atatürk. Retrieved January 30, 2010, from http://en.wikipedia.org/wiki/Mustafa_Kemal_Atatürk

Wikipedia. (2010g). Ontological alignment. 2010, from http://en.wikipedia.org/wiki/Ontology alignment

Wordnik. (2010). Wordnik. from http://www.wordnik.com/

YouTube. (1994). $\quad$ Riverdance@Eurovision $\quad 1994 . \quad$ Retrieved $\quad J a n u a r y ~ 24, \quad 2010, \quad$ from http://www.youtube.com/watch?v=jWyhH5z92ps

YouTube. (2004a). ESC Eurovision 2004 TURKEY-İstanbul Opening. Retrieved January 24, 2010, from http://www.youtube.com/watch?v=ICTx9ILlqBM\&NR=1

YouTube. (2004b). Fire of Anatolia@Eurovision Turkey_Full Version (from German TV). from http://www.youtube.com/watch?v=1709-M9jZ10\&feature=related

Български турци от село Бояна (Кокарджа) варненско, облечени в типични носии на заможни, млади мъже, с бели пояси и богато подшити с гайтани горни дрехи - около 1880-1890г. Retrieved January 17, 2010, from http://www.lostbulgaria.com/?p=1900

Вестник "Марица". Вестник "Марица". Retrieved January 17, 2010, from http://www.marica.bg/show.php?id=9047

Георгиева, М. (2009). Мадарски конник в Афганистан. Списание *8* - за твоя космос, from http://www.ossem.eu/article.aspx?pg=ar154

Орела, М. (2008). Lozan Anit1, Edirne. from http://www.flickr.com/photos/mihalore1/2563847728/

Орела, М. (2010). Мадарският конник, Мадара. http://www.flickr.com/photos/mihalorel/4304720466/ 